\title{
ISOLATION AND CHARACTERISATION OF MICRO-ORGANISMS WITH INDUSTRIAL IMPORTANCE FROM SISAL BOLE ROTS
}

\author{
"Consolatha J. N. Mhaiki, EnockMasanja, "*Jamidu H. Y. Katima,, \\ Gunaratna K. Rajarao, ${ }^{* * *}$ Gunnel Dalhammar
}

\footnotetext{
"Corresponding author;Sokoine University of Agriculture (SUA),Department of Soil Science, P.O. Box 3008, Morogoro, Tanzania.

${ }^{* *}$ College of Engineering and Technology (CoET),Department of Chemical and Mining Engineering, P.O. Box 35131, Dar Es Salaam, Tanzania

${ }^{* * *}$ School of Biotechnology, (Applied Environmental Microbiology), Alba Nova University Centre, Royal Institute of Technology (KTH), Roslagstullsbacken 21, SE - 10691 Stockholm, Sweden. Email;konsolatha@yahoo.com; cmhaiki@suanet.ac.tz; emasanja@udsm.ac.tz;jkatima@udsm.ac.tz;gunar@biotech.kth.se
}

\begin{abstract}
Investigation of microorganisms naturally acclimatized to Agave hybrid H 11648 (sisal bole rot) was conducted, with the aim of isolating and characterizing Aspergillus niger strains for industrial use. Microorganism were identified morphologically and then confirmation made by polymerase chain reaction (PCR). Results showed the existence of four major groups, listed in order of abundances as follows; Aspergilli (36.0 \pm 0.8$) \%$, Penicillin

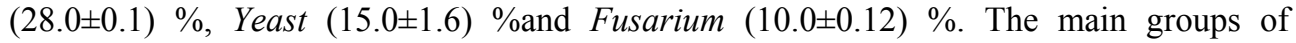
Aspergilli strains were $A$. nidulans, $A$. tamari and $A$. niger in ratios $(3: 2: 2)$, respectively. Several endo-spore forming non-enteric gram (-) rods and coccid bacteria identified by API $20 \mathrm{NE}$ identification systemincluded,Brevundimonas diminuta sp, Shewanella putrefaciens $s p$, Brevundimonas vesicularis $s p$ and Pasteurella $s p$. Results showed that sisal bole rot stems hosts a high bio-diversity of microorganism species other than A. niger. Exploitation of the individual strains is recommended. This could eventually produce strains for precursors of industrially and therapeutically metabolites.
\end{abstract}

Key words: Sisal, filamentous-fungi, Aspergillus niger, yeast, non-enteric gram -ve bacteria

\section{INTRODUCTION}

Microbial communities are ubiquitous in the environment and have been implicated in various processes including opportunistic infections to living organisms of both the animal and plant kingdoms. Microorganisms also play a significant role in the global carbon cycle and provide a wide range of hydrolytic and oxidative enzymes, which are usually involved in digestive systems, breaking down of plant carbohydrates and lignocelluloses. Varieties of these enzymes are also important in chemical and for biotechnology industries. The rapid humification (rot) of carbohydrate rich sisal plants "carbon-cycling" by fermentative microorganisms is not desired in sisal agronomy as it lowers sisal fiber yields. Sisal bole rot (SBR) destruction by fungi has been well documented and strong measures have been emplaced to wade away the chances for manifestation such as proper tillage drainage and moisture control (KATANI Ltd. 1994; Lock, 1969). Since sisal life cycle extends to about 10 to 12 years, this time lapse supports a high microbial biodiversity, for that matter sisal bole rot manifestation suggested the survival of beneficiary microorganisms and that little effort might be needed for the isolation of strains for industrial production purposes. In principle the microbiology of sisal bole rots seems to be limited to essentially some bacteria, fungi and yeast species those which are tolerant to harsh 
environmental conditions characterized by comparative low pHs' of sisal saps, hard lignified stem-bark and cuticle layer that covers plant leaves (Taiz and Zeiger, 1998). Presence of carbohydrate in forms of a complex inulin molecule necessitates molecular size reductions by hydrolysis prior the microbial assimilation. This could be another reason for the coexistence of high microbial diversity, where by some produces hydrolytic enzymes while others get access to the readily assimilated hydrolysates sugars. During the extreme dry conditions of Tanzanian coastal summer, sisal plants respiration and osmosis is regulated by the stored complex inulin-carbohydrate (Edelman and Jefford, 1968). Either at this point essentially most of the microorganisms enter the dominancy, forms spores or form a symbiotic alliance that is; waiting for others to break huge molecules for them to assimilate and survive.

This research therefore was aimed to isolate and characterize microorganisms, with industrial importance from sisal bole rots (SBR) and apply them in selective fermentation production of bio chemicals. Research findings is presumed to be applied in promotion of utilization of the whole sisal plant, which could lead to the expansion of production and marketing of non-traditional sisal products for example, bio ethanol enzymes and carboxylic acids (CFC/UNIDO 2003;KATANI Ltd. 1994).

\section{MATERIALS AND METHODS}

\section{Materials}

Sisal boles rot chunks from Agave $\mathrm{H}$ 11648, were randomly collected from Highland estate, and were handled aseptically. Samples were analyzed the same day; otherwise, stated sisal boles were frozen below $-20^{\circ} \mathrm{C}$ in a deep freezer. Microbial culture media used were from Sigma Aldrich and Fluka that is Sabouraud Dextrose Agar (SBD) CM0041, Oxytetracycline Yeast Extract Agar (OGYE) 66481 HiCrome, Czapek yeast autolysate agar (CYA) potato dextrose agar (PDA)were purchased from Sigma Aldrich. Standard methods and protocols by the respective suppliers were used throughout (AOAC, 1995; Collins et al., 1998; Domsch et al., 1980; Tran et al., 1998).Isolation recovery screening and confirmation of indigenous $A$. niger from sisal bole rot was done at the UDSM-College of Engineering and Technology (CPE) and KTH Environmental Biotechnology Department Sweden (KTH-Bio). Representative samples were sent to Nadicoma sequencing company in Germany (Nadicom, 2006).

\section{Isolation of Microorganisms}

Isolation and enumeration of microorganisms was done by sub sampling of 10 small chunks of sisal bole rot stems measuring 1-2 mm diameter and weighing $0.2-0.3 \mathrm{gm}$. These were gently crushed, and soaked in $5 \mathrm{ml}$ deionized sterile water for 5 minutes. A serial tube dilution for viable cells counting was performed at the dilution range between $10^{-1}$ and $10^{-7}$. Total microbial population numbers was determined by a pour plate count technique on agar plates (PCA) after inoculation and culturing at temperatures $20^{\circ} \mathrm{C}, 30^{\circ} \mathrm{C}$ and $45^{\circ} \mathrm{C}$ for 24 , 48 and 72 hours (AOAC, 1995; Collins et al., 1998; Guarro et al., 1999;Domsch et al., 1980; Johnson and Case 2004; Tran et al., 1998). The growth media was made up by incorporating hundred millilitres of sisal Inulin so as to ensure that media used are suitable for the survival of indigenous species. Pure cultures of Aspergilli were differentiated by using special media Tryptone Agar (Tryptone) Yeast Extract Agar (YEA) Sabourad Dextrose (SB), Oxytetracycline Yeast 
Extract Agar (OGYE), and incubation done at $30^{\circ} \mathrm{C}$ for 7 days. Filamentous fungi and yeasts were also enumerated from acidified YEA, along with some endo spore forming bacterial that survives the acidic conditions. Isolated strains were purified, and maintained on NA and PDA slants (Johnson and Case, 2004).

\section{Systematic and molecular-biological analyses}

Macromorphologic identification were done by the powerful light microscope and Olympus BX-51 fluorescence research microscope that incorporates the advanced phase contrasting (Nomarski DIC system) and the Sony DXC960MD incorporating a 3 chip CCD video camera system. These were available at the KTHBio Laboratory. Cultures expressions on agar plates differed in terms of micro- and macro morphological features according to differential media used and microorganisms in question (Collins et al., 1998; Domsch et al., 1980). While systematic identification was done using taxonomical keys by (Guarro et al., 1999; Pitt, 1993), confirmation was done by subjecting microorganisms to (PCR) polymerase chain reaction identification after method by (Gardes and Bruns, 1993; Kure et al., 2003). While polymerase chain reaction identification was done using Sequences of Oligonucleotides Primers "SOP" AD-02, standard primers used had the following Internal Transcribed Spacer (ITS) sequences:

ITS $1=5{ }^{\prime}-$ TCCGTAGGTGAACCTGCGG- $3^{\prime}$ and ITS $4=5^{\prime}$-TCCTCCGCTTATTGATATGC-3';

ITS region was preferred because it is the most widely sequenced DNA region in fungi and it is typically most useful for molecular systematic across species level and even within species, as it allows selective amplification of fungal sequences (Gardes and Bruns, 1993). Genomic DNA samples for the Aspergilla was prepared according to Applichem manufacturer's instructions by taking the grown colonies from the respective plates, with an inoculating loop and directly inserting into the DNA Applichem extraction kit. The sequences of the oligonucleotides primers (SOP) used had the following sequence:

M13P = 5'-GAG GGT GGC GGT TCT-3' .

Evaluation of the PCR products of the M13P-PCR were applied on 2\% TAE gel and separated at 100 volts, using the agarose gel which was stained with a $0.1 \%$ ethidium bromide solution and photographed (Gardes and Bruns, 1993 Kure et al., 2003). After culturing in NA, non-enteric Gram (-) strainsbacteria colony forming units (c.f.u) were carefully observed under powerful light microscope and confirmed by the API 20 NE identification system by "bioMérieux Bv, Boxtel, Netherlands" (Johnson and Case, 2004).

\section{RESULTS AND DISCUSSION}

\section{Microorganisms isolation screening and identification}

As experiments were carried out in three replicates, results were presented as mean values in tabular form (Table 1 to 6). Four major groups of fungi and yeasts resulted. Individual group isolated were named and averaged in order of abundances; Aspergilli $\quad(36.0 \pm 0.8) \quad \%, \quad$ Penicillin $(28.0 \pm 0.1) \%$, Yeast $(15.0 \pm 1.6) \%$ and Fusarium (10.0 \pm 1.2$) \quad \%$. Remaining fraction included various spore forming bacteria species, of which the dominant were bacilli and coccid. Also seen were coma shaped but were not considered in this study (Table $\mathbf{1}$ and 2). Dominant Aspergilli species observed were Aspergillus nidulans, Aspergillus tamari and Aspergillus niger in ratios $(3: 2: 2)$ consecutively. 
Isolation and Characterization of Microorganisms, with Industrial Importance from Sisal Bole Rots

Table 1: Total microorganisms counts in (SBR) chunks grab samples $(n=10)$.

\begin{tabular}{|l|l|l|l|l|l|l|l|}
\hline \multirow{2}{*}{$\begin{array}{c}\text { Dilution } \\
\text { range }\end{array}$} & $\begin{array}{c}\text { c.f.u -count } \\
\text { range }\end{array}$ & \multicolumn{6}{|c|}{ Average counts (x10 $0^{5}$ c.f.u ) } \\
\cline { 3 - 8 } & & Mould & $\begin{array}{l}\text { Bacteri } \\
\mathrm{a}\end{array}$ & Fungi & Yeast & Others & Total \\
\hline $10^{-2}$ & 80 and above & ND & ND & ND & ND & ND & ND \\
\hline $10^{-3}$ & $36-42$ & 2.00 & 4.00 & 5.50 & 1.98 & 0.67 & 13.48 \\
\hline $10^{-4}$ & $30-40$ & 2.08 & 3.31 & 6.60 & 2.43 & 0.58 & 14.42 \\
\hline $10^{-5}$ & $28-32$ & 1.80 & 1.00 & 7.40 & 1.62 & 0.86 & 11.82 \\
\hline $10^{-6}$ & $25-30$ & 3.60 & 4.30 & 6.80 & 5.09 & 0.78 & 19.79 \\
\hline $10^{-7}$ & 15 and less & ND & ND & ND & ND & ND & ND \\
\hline $\begin{array}{l}\text { Total } \\
\text { counts }\end{array}$ & & 9.48 & 12.61 & 26.3 & 11.12 & 2.89 & 62.40 \\
\hline & & & & & & & \\
\hline & Min & 1.80 & 1.00 & 5.50 & 1.62 & 0.58 & 10.50 \\
\hline & Max & 3.60 & 4.30 & 7.40 & 5.09 & 0.86 & 21.25 \\
\hline & Average & 2.37 & 3.15 & 6.58 & 2.78 & 0.72 & 15.60 \\
\hline & Stdev & 0.83 & 1.49 & 0.79 & 1.58 & 0.12 & 4.81 \\
\hline & Average (\%) & 15.19 & 20.21 & 42.15 & 17.82 & 4.63 & 100 \\
\hline
\end{tabular}

$\mathrm{ND}=$ not determined above 80 and below 15 c.f.urange so as to avoid uncertainty errors
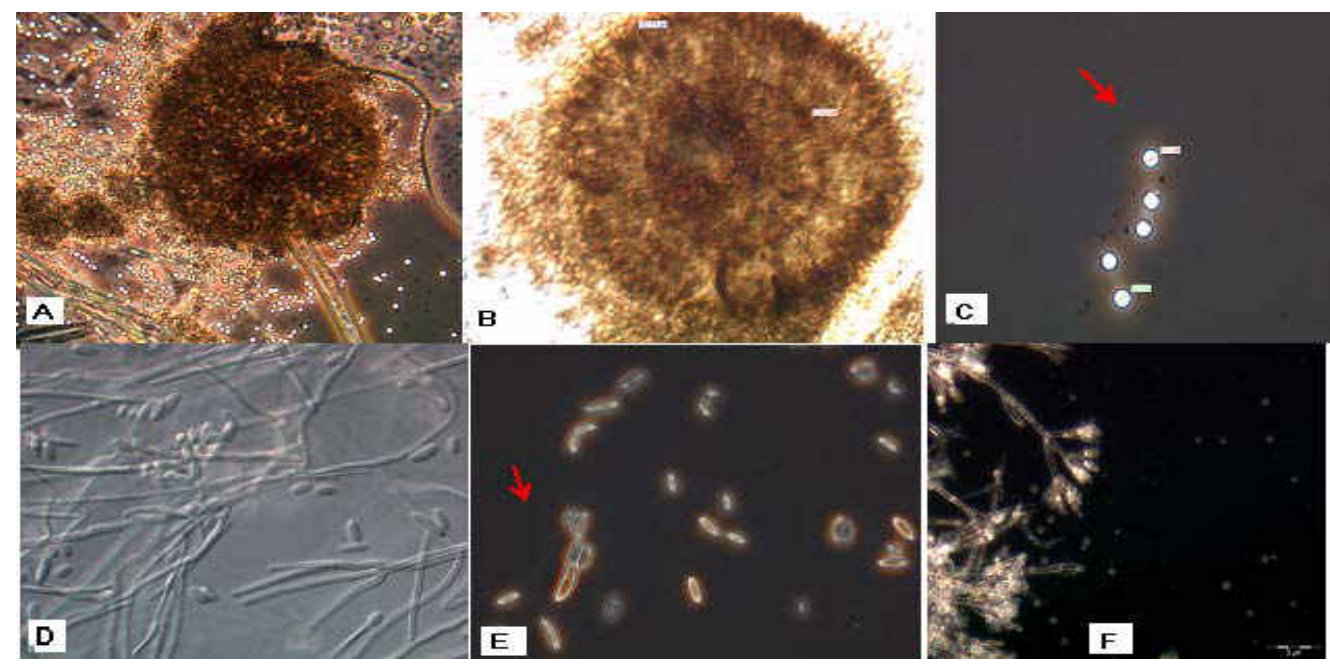

Figure 1: Morphologies ofsome microorganisms of industrial potential from (SBR)

Morphologic differences between Macroscopically Aspergillus niger Aspergillus niger and other filamentous colonies on surface Czapeck agar plates at fungi

$30^{\circ} \mathrm{C}$ were initially white, and then blackened with conidial production. On

Shown in Figure1 are some reverse side, colonies were pale yellow microorganisms of industrial potential from sisal bole rot stems; (A) A. niger Conidia, (B) transect of $A$. niger Conidia, (C) A. niger spores, (D) Fusarium sp, (E) Banana spores Fusarium solani and (F) Septate-conidiophores for Penicillin $s p$. and grew radialy. Five days old $A$. niger hyphae became distinctive septate and their respective conidia long and smooth, and hyaline measured (500 to $800 \mu \mathrm{m}$ ). The typical Aspergilli featured biseriate characteristic was clearly seen under the 
microscope. Presence of a metulae and their corresponding conidiogenous phialides, while metulae and phialides covering entire vesicle to form a rough fruiting conidia head whose diameter measured at $132.78 \pm 0.02 \mu \mathrm{m}$ (A) and (B) in Figure1, was very conclusive also described by head, metula and phialide diameter values which were measured between 3.77 and $3.89 \pm 0.02 \mu \mathrm{m}(\mathrm{C})$.
Fusarium $s p$ colonies displayed characteristic banana like spores common to $F$. solani (D) and (E) in Figure 1, whereas penicillin $s p$ clearly showed their distinct septate conidiophores' with respective metulae and phialides appearing in branched form (Guarro, 1999; Pitt, 1993).

Table 2: Identifiable microorganism and their incidence in (SBR) grab samples $(\mathrm{n}=10)$

\begin{tabular}{|c|c|c|c|c|}
\hline Reference & $\begin{array}{l}\text { Morphological } \\
\text { Identification }\end{array}$ & c.f.u & $\begin{array}{l}\text { Microbe-count } / \text { g-sisal } \\
\text { bole } \operatorname{rot}(\% \text { c.f.u })\end{array}$ & Remarks \\
\hline OR5 & Yeast budding & $11.12 \times 10^{5}$ & $(15.0 \pm 1.6)$ & \\
\hline OR5 KTH & Yeast budding & & & For PCR \\
\hline OR5 NA & Yeast budding & & & For PCR \\
\hline $4 \mathrm{a}$ & Yeast single & & & \\
\hline 4a KTH & Yeast single & & & For PCR \\
\hline Wfus. & Fusarium solani & $7.42 \times 10^{5}$ & $(10.0 \pm 0.12)$ & For PCR \\
\hline Wfus KTH & Fusarium solani & & & \\
\hline BYF KTH & Aspergillus niger wild & $26.7 \times 10^{5}$ & $(36.0 \pm 0.8)$ & $\begin{array}{l}\text { PCR \& (citric } \\
\text { acid) }\end{array}$ \\
\hline BYF & Aspergillus niger wild & & & (citric acid) \\
\hline BWf KTH & Aspergillus tamarii & & & $\begin{array}{l}\text { For PCR\& } \\
\text { (citric acid) }\end{array}$ \\
\hline BWf & Aspergillus tamarii & & & \\
\hline BfK & Aspergillus nidulans & & & For PCR \\
\hline $\mathrm{Yf}_{1}$ & Aspergillus nidulans & & & For PCR \\
\hline $\mathrm{Yf}_{2}$ & Aspergillus nidulans & & & \\
\hline Pe Green & Penicillin & $20.8 \times 10^{5}$ & $(28.0 \pm 0.1)$ & \\
\hline Pe Gray & Penicillin & & & \\
\hline $\begin{array}{l}\text { White- } \\
\text { cream }\end{array}$ & Endospore coccid & $5.19 \times 10^{5}$ & $(7.0 \pm 1.5)$ & $\begin{array}{l}\text { API 20 NE } \\
\text { TESTS }\end{array}$ \\
\hline Off White & Endospore rods & $4.45 \times 10^{5}$ & $(6.0 \pm 1.5)$ & $\begin{array}{l}\text { API 20 NE } \\
\text { TESTS }\end{array}$ \\
\hline $\begin{array}{l}\text { Shiny } \\
\text { White }\end{array}$ & Coma motile species & $2.97 \times 10^{5}$ & $(4.0 \pm 1.5)$ & \\
\hline Others & & $2.89 \times 10^{5}$ & $(4.0 \pm 1.5)$ & \\
\hline
\end{tabular}

Table 3: PCR sequencing confirmation summary

\begin{tabular}{|l|l|l|l|}
\hline S/No Nadicom & Reference & Identified as & Remarks \\
\hline 449.1 & OR5 KTH & Pichia membranifaciens & \\
\hline 449.2 & 4a KTH & Clavispora lusitaniae & \\
\hline 449.3 & OR5 NA & Pichia membranifaciens & \\
\hline 449.6 & Wfus. & Fusarium solani & \\
\hline 449.7 & BYF KTH & Aspergillus niger & for CA production \\
\hline 449.8 & BWf KTH & Aspergillus tamarii & for CA production \\
\hline 449.9 & BfK & Aspergillus nidulans & \\
\hline 449.10 & Yf & Aspergillus nidulans & \\
\hline API 20 NE & Endospore coccid & & \\
\hline API 20 NE & Endospore rods & & \\
\hline API 20 NE & Motile species & & \\
\hline
\end{tabular}


Polymerase chain reaction (PCR) Confirmation and Genomic DNA Results

Polymerase chain reaction (PCR) sequencing results which are presented in Table 3showed high consistence with morphological identities done using taxonomical keys by (Guarro et al., 1999; Pitt, 1993). Concurrently, the genomic DNA results for Aspergilla fungi shown in Figure 2 indicated that samples 449.7-(BYF KTH) Aspergillus niger wild, Aspergillus nidulans strains 449.9-(BfK)and 449.10-( $\left.\mathrm{Yf}_{1}\right)$ seemed to be very close. Concurrently sample 449.8-(BWf KTH) Aspergillus tamarii showed a different pattern. These findings thus signified a need for a more intensive identification work at species level, so as to capture genomic evolution (Figure 2).
$\begin{array}{lllllll}M & 449.7 & 449.8 & 449.9 & 449.10 & \text { DSMZ } & \text { M } \quad+\end{array}$

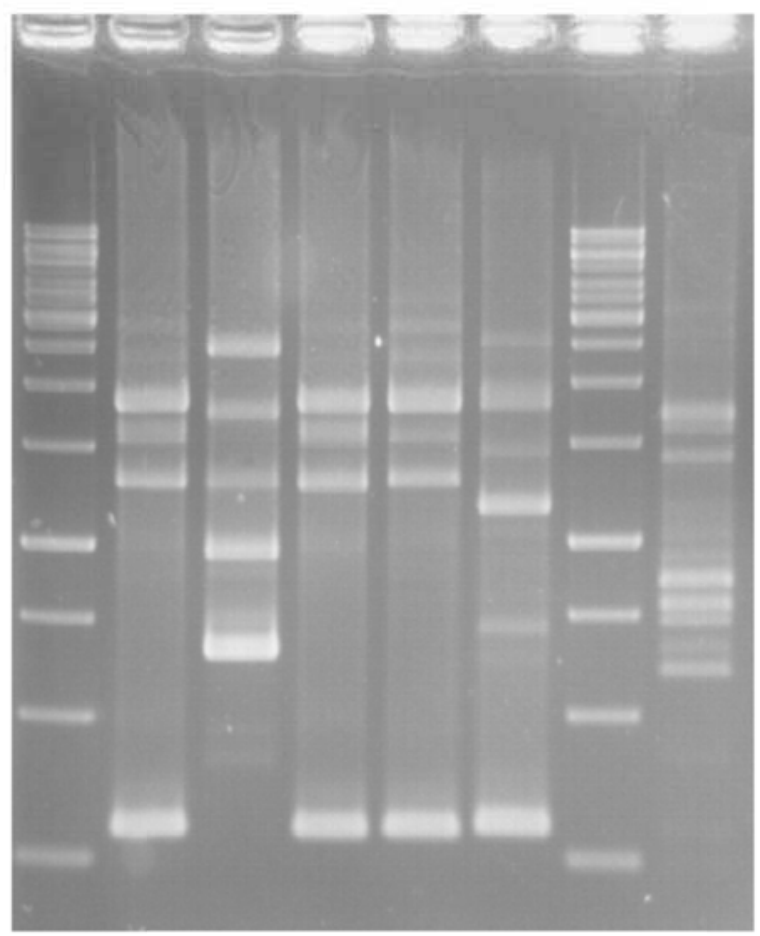

Figure 2: Genomic DNA results for Aspergilli fungi 
Table 4: Biochemical characterization of bacteria colonies viewed from above

\begin{tabular}{|c|c|c|c|c|c|c|c|}
\hline ID & 13 & $\begin{array}{l}\mathrm{RTN}_{4} \\
\mathrm{a}\end{array}$ & other & $\mathrm{RTC}_{4}$ & $\begin{array}{l}\mathrm{RTC}_{6} \\
\mathrm{a}\end{array}$ & $\mathrm{WA}_{4}$ & 7 \\
\hline Media & NA & NA & NA & $\mathrm{CZ}$ & $\mathrm{CZ}$ & WAYE & NA \\
\hline Temp ${ }^{\circ} \mathrm{C}$ & 30 & 30 & 30 & 20 & 20 & 30 & 30 \\
\hline Hrs & 24 & 24 & 24 & 24 & 24 & 24 & 24 \\
\hline $\begin{array}{l}\text { Average diameter of several } \\
\text { c.f.u (mm) }\end{array}$ & 2 & 1.5 & 2 & 1.5 & 3 & 1.5 & 3 \\
\hline General Shape: & Spr & Ro & Ro & Ro & Ro & Ro & Spr \\
\hline Gram Staining & $\begin{array}{l}\mathrm{G}(-) \\
\mathrm{R}\end{array}$ & $\mathrm{G}(-) \mathrm{C}$ & G(-) R & $\mathrm{G}(-) \mathrm{C}$ & $\mathrm{G}(-) \mathrm{C}$ & $\mathrm{G}(-) \mathrm{C}$ & $\begin{array}{l}\mathrm{G}(-) \\
\mathrm{R}\end{array}$ \\
\hline Catalase & $(+)$ & $(+)$ & $(+)$ & $(+)$ & $(+)$ & $(-)$ & $(+)$ \\
\hline Oxidase & $(+)$ & $(-)$ & $(+)$ & $(-)$ & $(-)$ & $(-)$ & $(-)$ \\
\hline Endospores & $(+)$ & $(+)$ & $(+)$ & $(+)$ & $(+)$ & $(+)$ & $(+)$ \\
\hline Oxygen demand & $(+)$ & $(+)$ & $(+)$ & $(+)$ & $(+)$ & $(+)$ & $(+)$ \\
\hline Minimal nutrient & $(+)$ & $(+)$ & $(+)$ & $(+)$ & $(+)$ & $(+)$ & $(+)$ \\
\hline Maconkey & $(-)$ & $(-)$ & $(-)$ & $(-)$ & $(-)$ & $(-)$ & $(-)$ \\
\hline $\begin{array}{l}\text { Starch Hydrolysis }(+) \text { clear } \\
\text { zone indicates } \\
\text { hydrolysis }\end{array}$ & $(+)$ & $(+)$ & $(+)$ & $(+)$ & $(+)$ & $(+)$ & $(+)$ \\
\hline Gelatin & $(+)$ & $(-)$ & $(+)$ & $(-)$ & $(-)$ & $(-)$ & $(+)$ \\
\hline Casein Hydrolysis & $(+)$ & $(+)$ & $(+)$ & $(+)$ & $(+)$ & $(+)$ & $(+)$ \\
\hline Litmus milk & $(+)$ & $(+)$ & $(+)$ & $(+)$ & $(+)$ & $(+)$ & $(+)$ \\
\hline Sulfur Indole Motility Test & $(+)$ & $(+)$ & $(+)$ & $(+)$ & $(+)$ & $(+)$ & $(+)$ \\
\hline Minimum agar & $(+)$ & $(+)$ & $(+)$ & $(+)$ & $(+)$ & $(+)$ & $(+)$ \\
\hline $\begin{array}{l}\text { MaConkey(-) Negative re } \\
\text { confirms G (-) for endo- } \\
\text { spores }\end{array}$ & $(-)$ & $(-)$ & $(-)$ & $(-)$ & $(-)$ & $(-)$ & $(-)$ \\
\hline $\begin{array}{l}\text { FE Negative re confirms } G \\
(+) \text { for endo-spore }\end{array}$ & $(+)$ & $(+)$ & $(+)$ & $(+)$ & $(+)$ & $(+)$ & $(+)$ \\
\hline FM(-)acid & $(-)$ & $(-)$ & $(-)$ & $(-)$ & $(-)$ & $(-)$ & $(-)$ \\
\hline
\end{tabular}

KEY:G (-) R = Gram-negative rods; G (-) C = Gram-negative cocci; (Spr) = Spreading; $(\mathrm{Ro})=$ Round irregular

Table 5: Bacteria colonies reaction to antibiotic (AB Biodisk) after $24 \mathrm{Hrs}$

\begin{tabular}{|c|c|c|c|c|c|c|c|c|c|c|}
\hline \multirow[t]{2}{*}{ ID } & \multirow[t]{2}{*}{ Media } & \multirow{2}{*}{$\begin{array}{l}\text { Tem } \\
\mathrm{p}^{\circ} \mathrm{C}\end{array}$} & \multicolumn{3}{|c|}{ Tetracycline } & \multicolumn{3}{|c|}{ Penicillin } & \multirow{2}{*}{$\begin{array}{l}\text { Aminogl } \\
\text { ycosides }\end{array}$} & \multirow{2}{*}{$\begin{array}{l}\text { Sulphon } \\
\text { amides }\end{array}$} \\
\hline & & & CL & TC & RI & PG & $\mathbf{A M}$ & GM & & \\
\hline 13 & NA & \multirow[t]{3}{*}{30} & (R) & (R) & (R) & (R) & (S) & (R) & (S) & (R) \\
\hline$\overline{R T N}_{4 a}$ & NA & & (IS) & (R) & (R) & (R) & (S) & (R) & & \\
\hline other & NA & & (R) & (R) & (R) & (R) & (R) & (IS) & (S) & (R) \\
\hline $\mathrm{RTC}_{4}$ & $\mathrm{CZ}$ & \multirow[t]{2}{*}{20} & (IS) & (R) & (R) & (R) & (S) & (R) & (S) & (R) \\
\hline $\mathrm{RTC}_{6 \mathrm{a}}$ & $\mathrm{CZ}$ & & (R) & (R) & (R) & (R) & (R) & (IS) & (S) & (R) \\
\hline $\mathrm{WA}_{4}$ & WAYE & \multirow[t]{2}{*}{30} & (R) & (R) & (R) & (R) & (R) & (IS) & (S) & (R) \\
\hline 7 & NA & & (R) & (R) & (R) & (R) & (R) & (IS) & (S) & (R) \\
\hline
\end{tabular}


KEY: (ID) = Colony identity;(IS)-(S) = Intermediate - Sensitive to systemic infection dosage has to be concentrated to organs; $(\mathrm{S})=$ Sensitiveto systemic infection; $(\mathrm{R})=$ Resistantto $\quad$ systemic infection; $\mathbf{C L}=$ Chloramphenicol $30 \mu \mathrm{g}$; TC $=$ Tetracycline $30 \mathrm{mg} ; \quad \mathbf{R I}=$ Rifampicines $2 \mu \mathrm{g} ; \mathbf{A M}=$ Ampicilin $10 \mu \mathrm{g} ; \mathbf{G M}=$ Gentamycin $30 \mu \mathrm{g} ; \mathbf{S M}$ $=$ Streptomycin $30 \mu \mathrm{g} ; \mathbf{S U}=$ Sulphonamide Trimethoprim $250 \mu \mathrm{g}, \quad \mathbf{P G}=$ Benzyl penicillin $100 \mu \mathrm{g}$. Shown in Table 5, bacteria isolates were found to be resistant to most common antibiotics. However in very few cases bacteria reactions to antibiotics was rated resistant to intermediate - sensitive to systemic infections, and colonies moderately reacted to either of the following antibiotic; Chloramphenicol, Ampicilin and Gentamycin. This suggested that if either of these drugs is to be used, the dosages have to be concentrated to organs.

Table 6: Bacteria coloniesreactions to API 20 NE TESTS

\begin{tabular}{|c|c|c|c|c|c|}
\hline \multirow{2}{*}{$\begin{array}{l}\text { Colony } \\
\text { ID }\end{array}$} & \multirow[t]{2}{*}{ Media } & \multicolumn{3}{|c|}{ API 20 NE } & \multirow[t]{2}{*}{ Suggested nomenclature } \\
\hline & & $\begin{array}{l}\text { Temp } \\
{ }^{\circ} \mathrm{C}\end{array}$ & $\begin{array}{l}\text { code }-24 \\
\text { hrs }\end{array}$ & $\begin{array}{l}\text { code }-48 \\
\text { hrs }\end{array}$ & \\
\hline 13 & NA & 30 & 1510004 & 1510004 & $\begin{array}{l}\text { (B. dim) synonym, (P. dim)OR } \\
\text { (S. put) }\end{array}$ \\
\hline $\mathrm{RTN}_{4 \mathrm{a}}$ & NA & 30 & 1430000 & 1430000 & (B. ves) OR (Pas) \\
\hline Other & $\mathrm{NA}$ & 30 & 1510004 & 1510004 & (B. dim) \\
\hline $\mathrm{RTN}_{4 \mathrm{a}}$ & $\mathrm{CZ}$ & 20 & 1430000 & 1430000 & (B. ves) OR (Pas) \\
\hline RTC $_{6 \mathrm{a}}$ & $\mathrm{CZ}$ & 20 & 1600000 & 1600000 & $(B r u)$ \\
\hline $\mathrm{WA}_{4}$ & WAYE & 30 & 400000 & 400000 & (B. ves) OR (Pas) \\
\hline $\mathrm{TN}_{3 \mathrm{~b}}$ & NA & 30 & 430000 & 1430000 & (B. ves) OR (Pas) \\
\hline
\end{tabular}

KEY: $(B$. dim $)=$ Brevundimonas diminuta $s p ;(B$. Ves $)=B$. vesicularis; $(P$. dim $)$ $=$ Pseudomonas diminuta; $(S$. put $)=$ Shewanella putrefaciens sp; $(B)=$ Brucella sp; $($ Pas $)=$ Pasteurella $s p ; \mathrm{ID}=$ Identity

Shown in Table 6, the dominant bacteria sp are B. Diminuta, S. Putrefaciens, B. vesicularis and pasteurella sp. Bacterial colony ID 13 tested $(+\mathrm{Ve})$ in respect to $\mathrm{NO}_{3}$ $\& \mathrm{~N}_{2}$ test however were identified as $B$. Vesicularis.

Biochemical characterization and API $20 \mathrm{NE}$ identification

A combination of standard biochemical tests and assimilations tests, are supported by the API $20 \mathrm{NE}$ Identification system for non-enteric Gram (-) rods done at 24 and 48 hours. The growth guide for API 20 NE Identification system was adapted in characterization of the non-fermentingmetabolizing bacteria (Tables 4 to $\mathbf{6}$ ). The standardized inoculums picking with a low bacterial concentration using a $(0.5$ $\mu$ l) micro pipette tip from a freshly refined cultures, guaranteed reliability of this method, while eliminating the contaminants from mixed cultures and subcultures.

\section{DISCUSSION}

Microbial sampling was done during the humid rainy season, under the assumption that the conditions were suitable for the 
proliferations of the fungal diseases. Despite to the fact that the black sisal bole rot has been occasional spotted to some injured individual plants and those under extremely stress conditions, the evidence on existence of spontaneous fungal out breaks were infrequently encountered. This results which are supported by literature cited indicate that sisal bole rot is very rich in microbe biodiversity specifically mould fungi and some endospore forming bacteria communities. Concurrently under the normal circumstances sisal plants showed a high immunity to microbial diseases (CFC/UNIDO, 2003; Lock, 1969).

In general terms both microorganisms isolates assimilated raw sisal inulin and used it as the sole carbon source. Most of sisal bole rot isolated fungi species were good in processing raw sisal juice, and strains are known to have a high potential for industrial use, for example strains of Aspergillus niger are known to produce citric acid (Kubicek et al., 1994). While penicillin, yeast and fusarium strains are used in enzyme and drugs manufacturing (Masih and Paul, 2002). In this study yeast species that were suspected to be responsible for the volatile alcohol stench while creating competitions with other moulds were not comprehensively investigated thus suggesting further considerations for future studies.

The encountered co-existence of moulds and bacteria was probably due to the inherent symbiosis. Among these, the motile and endo spore forming bacteria were common isolates. These were identified by using the API 20 NE TESTS, and named as; Brevundimonas diminuta $s p$, Shewanella putrefaciens $s p$, Brevundimonas vesicularis $s p$ and Pasteurella sp (Ngonyani, 2010). The identified strains were able to hydrolyze starch but not glucose(Table 4). The current study suggested that while bacteria strains preferred complex form of carbohydrate, they were able to assimilate starch and were resistant to common antibiotics as indicated in (Table 5).

\section{CONCLUSIONS}

Agave hybrid H 11648 (sisal bole rot) has got high bio-diversity of microorganisms naturally acclimatized to inulin rich environment. The identified four major groups of fungi and yeasts namely Aspergillus niger, Penicillin, Yeast and Fusarium suggested further tests on their versatile use in selective fermentation processing of useful metabolites. The existence of endo-spore forming nonenteric Gram (-) rods and coccid bacteria, suggests some possible symbiosis and competition pattern that needs a lengthy investigation. The isolated fungi strains, for example Aspergilli niger was considered as the potential citric acid production strain with sisal inulin hydrolysates being used as feed stock. With less strenuously manipulations fungi strains acclimatized to inulin rich saps are presumed to be in better position for future selective industrial fermentation processing of useful metabolites. The same analysis suggests that further rigorous screening is required for the identification of missed strains.

\section{ACKNOWLEDGEMENTS}

The authors would like to express their sincere tribute to the late Prof Lennart Nilson of KTH; his contribution before his premature death is highly appreciated.

\section{REFERENCES}

AOAC (1995). The Official Standard Methods of Analysis $16^{\text {th }}$ ed., Association of Official Analytical Chemists Washington DC.

Collins, C. H., Lyne, P. M., and Grange, J. M. (1998). Microbiological Methods: A Laboratory Manual $7^{\text {th }}$ ed., pp 493 Butter-worth Heinemann Publishers. 
Common Fund for Commodities/United Nations Industrial Development Organization 'CFC/UNIDO' (2003). Example of Project Formulation for CFC Co-financing Cleaner Integral Utilization of Sisal Waste for Biogas and Bio-fertilizers, Location of the project:

Tanzania, http://www.unido.org.

Domsch, K. H., Gamsch, W., and Anderson, T. H. (1980). Compendium of Soil Fungi: Vol. 1, Academic Press, and London.

Edelman, J., and Jefford, T. G. (1968). The mechanism of factor metabolism in higher plants as exemplified in Helianthus Tuberosm, New Phytol., Vol. 67, pp. 517-531.

Gardes, M., and Bruns, T. D. (1993). ITS primers with enhanced specificity for basidiomycetes - application to the identification of mycorrhizae and rusts., Mol. Ecol. 2: 113-118.

Guarro, J., J. Gene, and Stchigel, A. M. (1999). Developments in Fungal Taxonomy, Clinical Microbiology Reviews, Vol. 12, No. 3, pp. 454-500.

Johnson, T. R., and Case, C. L. (2004). Laboratory Experiments, In: Microbiology: $7^{\text {th }}$ ed. Pearson Benjamin Cummings Publishers, pp. 434.

Katani Ltd (1994). The Sisal Bole Revaluation Project, A Proposal submitted at the Conference on University - Industry Science Partnership in Africa (UNISPAR) Arusha, Tanzania.

Kubicek, C.P., Witteveen, C. F. B., and Visser, J. (1994). Regulation of organic acid production by Aspergilli, In: Powelli, K. A., (ed.), The genusAspergillus: Plenum Press. New York, pp. 35-145.

Kure, S., K. Kojima, A. Ichinohe, Aoki, Y. Suzuki, Y., and Matsubara, Y. (2003).A comprehensive mutation analysis of GLDC, AMT, and GCSH in glycine encephalopathy. $J$ Inherit Metab Dis, Vol. 26, No. 2, pp. 66.

Lock, G. W. (1969). Sisal: Report on Thirty years' of sisal research in Tanzania, 2nd Ed., pp. 200 - 365, Department of Agriculture Longmans London.

Masih, E. I., and Paul, B. (2002). Secretion of $\beta-1,3-$ Glucanases by the Yeast Pichia membranifaciens and Its Possible Role in the Biocontrol of Botrytis cinerea Causing Grey Mold Disease of the Grapevine. Current Microbiology, Vol. 44, pp. 391-395.

Nadicom (2006). The PCR-sequencing Company: physical and correspondence address; Nadicom Gesellschaft für angewandte Mikrobiologie mbH Hertzstr. 16 76187 D-Karlsruhe and Pflanzogarten 10, D-35043, Marburg-Bauerbach, Germany: available online at $<$ http://wwwnadicom.de>

Ngonyani, C. J. (2010). The Utilization of Sisal Bole Juice - Inulin as an alternative chemical feedstock in citric acid production: $\mathrm{Ph}$ D Thesis University of Dar Es Salaam Tanzania.

Pitt, J. I. (1993). Speciation and evolution in Penicillium and related genera. pp 113-117.In: D. R. Reynolds, and J. W. Taylor (eds.), Fungal holomorph mitotic meiotic and pleomorphic speciation in fungal systematics. CAB International Wallingford, United Kingdom.

Taiz, L., and Zeiger E. (1998). Plant Physiology: $2^{\text {nd }}$ ed., pp 287-297, Sinauer Associates Inc. Publishers, Sunderland Massachusetts.

Tran, C. T., Sly, L. I., and Mitchell, D. A. (1998). Selection of a strain of Aspergillus for the production of citric acidfrom pineapple wastes in solidstate fermentation. World J Microbiol. Biotechnol., Vol. 14, pp. 399-404. 